\title{
External Debt, External Reserves, Debt Service Costs and Economic Growth: Implications for the Nigerian Transport Sector
}

\author{
Richard C. Osadume ${ }^{1 *}$ and Edih University Ovuokeroye ${ }^{1}$
}

${ }^{1}$ Nigeria Maritime University, Department of Marine Economics \& Finance, Okerenkoko, Nigeria; Email: richard.osadume@nmu.ed.ng,oweilade123uni@gmail.com

*Corresponding Author: Richard C. Osadume

Received: 1 February 2021; Revised: 15 April 2021; Accepted: 31 August 2021; Published: 18

November 2021

\begin{abstract}
The objective of the study presented in this article is to examine the relationship between external debt (EXDT), external reserves (EXRS), total debt service costs (TDS) and Nigeria's economic growth (RGDP) and how these variables impact on the Nigerian transport economy employing profligacy theory. The study used secondary data for Nigeria for the period 1979 to 2019 obtained from the International Debt Office (WBG). The econometric techniques used include OLS, Granger causality and Engle-Granger cointegration at a 0.05 confidence level. The results show that EXDT has a statistically significant negative relationship with EXRS, with no statistically significant relationship existing with RGDP and TDS in the short term. All the variables showed significant cointegration over the long term, with the conclusion that the relationship between EXRS and EXDT is negatively significant in the short term, while the other variables are insignificant. The recommendations of the study include, that the government and monetary authorities should endeavour to reduce the creation of foreign debt for nonreproductive projects in key sectors due to its adverse effect on external reserves, and instead pursue aid, grants and domestic long-term loan options necessary for effective growth of the transport and other key sectors of the economy.
\end{abstract}

Keywords: External debt, infrastructure, development, external reserves, debt service costs, Transport sector

\section{Introduction}

External debt, external reserves and debt service costs are indicators of economic growth because they influence the growth trajectory of an economy either positively or negatively. The growth of an economy is the product of the economic policy of a country [1]. It is trite to say that economic policy determines the amount of external debt, reserves and debt servicing measures that need to be undertaken by the government of a country. Expansionary policy necessitates external borrowing, the reduction of external reserves, the prolongation of the repayment of debt, and increased debt service costs, while contractionary economic policy moves to restrict the size of external loans, boost external reserves and eliminate debt service costs. The drivers of growth in an economy are the instruments established or designed by the policy framework derived from conscious and objective economic planning. These instruments take the form of natural resources, technologies, human capital, loans, external reserves, debt servicing models, fiscal and monetary policies, bilateral and multilateral trade agreements, political stability and good governance. Economic growth is therefore a function of and a combination of socioeconomic and political parameters deliberately harnessed to achieve the desired results. 
External debt is that portion of public debt borrowed from foreign countries or issued in Euro bonds to sponsor capital projects [2]. The Debt - to - GDP indicator is a method for determining the importance of a nation's debt. For admission into the European Union's euro currency, it must not exceed 60 percent of GDP [3]. [2] affirm that external debt, if managed with prudence, enhances economic growth and development. However, huge external debt above the standard threshold crushes economic growth [4]. When taking into consideration comparative advantages into the growth process, for example in the form of natural or man-made factors, global competition and technologies, developing countries cannot survive and grow their economies without a conscious plan for borrowing (foreign or domestic loans). Unpaid external debt depletes external reserves and increases the burden of servicing debts due to lag/default. External reserves are a viable source for solving problems regarding external imbalances [5]. External reserves refer to the overage in the balance of payments for a calculated period [6]. It is the accumulated balance of foreign exchange surpluses of a nation. It is a stimulus to shortfalls in foreign exchange receipts and value of domestic currency [7].

From extant studies, the position of external reserves relative to external debt, total debt service costs and economic growth appears unclear as various authors have argued on opposing sides. Hence, this study is an attempt to evolve a consensus position between the conflicting research views and critically ascertain the exact relationship between external debt, external reserves, total debt service costs and economic growth, and build a step further in considering how the interplay of these variables can contribute to effective national and global transport system development. The aim of the research presented in this article is to determine the nexus between external debt, external reserves, total debt service costs and economic growth in less developing countries, in this case based on Nigeria between 1979 and 2019. The relevant hypothesis will argue in favour of there being an insignificant relationship between external debt, external reserves, total debt service costs and growth in the economies of less developing countries. The study will serve as a guide to policy formulators with respect to managing Nigeria's foreign reserves, which have been declining in recent times.

\subsection{Literature Review}

In 2012, the public debts of the United States and the United Kingdom amounted to USD 56,308 billion and USD 2,064 billion, respectively. This is the equivalent of 31.3\% and 3.7\% of world public debt [8]. In the same year, the gross debt of Nigeria was USD 10,402 billion, higher than that of the United Kingdom. This shows the significance of loans for the advancement of an economy, even developed economies of the world. According to [2,9], Nigeria's external debt burden (interest rates, debt service costs) is watering down her revenues due to fluctuations in exchange rates and prolonged default. The 2021 National Budget of Nigeria set aside NGN 3.1 trillion out of NGN 10.8 trillion for debt servicing only. This is a huge drain on total revenues. Despite the cancellation of external debt by members of the Paris Club and other creditors, the majority of Nigerians continue to live below the poverty line, the infrastructure is in a high state of decay, and there is structural long-term unemployment due to political bias and endemic corruption [2]. Hence, this study examines the effects of external debt, external reserves and debt service costs on Nigeria's economic growth.

Interest represents charges on contracted loans, although there are exceptions. In the majority of cases, the interest rate is determined by the lending institutions, and sometimes influenced by the bargaining powers of the contracting parties. In circumstances where the obligor is unable to settle their 
loan (debt) at the time it is due, debt servicing comes into focus, which creates an additional burden for the borrowing nation. At times, the amounts involved to service the debts may erode the benefits of the capital borrowed. This is particularly the case if the capital is not utilized in productive ventures or projects which yield high returns. Debt, irrespective of whether it is foreign or domestic, requires collateral to facilitate the release of the agreed funds. External reserves fulfill this role for external debt received from external sources such as the IMF, World Bank, AFDB or other lending nations. According to [5] and IMF (2003), external reserves entail government reserves (foreign assets) in international institutions that are controlled by the monetary authorities (IMF, World Bank) for the direct financing and regulation of the balance of payments through intervention in the exchange markets. Foreign reserves have been seen as having a large influence on external debts because they represent a significant source of financing for external imbalances [10].

Transportation plays a vital role in global trade as over $95 \%$ of world trade is conducted over the seas and virtually all parts of the world are interconnected by multimodal systems of transport [20]. A good interlink of the water transport and rail-road transport systems are essential for rapid industrialization of emerging economies. Thus, borrowing for the purpose of financing effective transportation network to boost global is considered a very productive project in an economy because of the ripple revenue effects [21].

\subsection{Theoretical Studies}

Is the purpose of borrowing, whether from foreign or domestic institutions, to boost the growth and development of a country's economy including its transport sector? Demanding explanations on how successive governments appropriated such loans leads to questionable responses. Scholars argue that political instability compounded by endemic corruption in developing countries has worked against the judicious application of these loans [2]. This study considers the profligacy theory because it explains the reasons for the wastage of scarce resources. This thesis supports the argument that debt crises arise from weak government institutions and large scale corruption. Some scholars contend that adverse terms of trade, policy deficiency, poor governance, non-concessional loans from creditors and political factors promote wastage and economic problems $[2,11]$. The need for the prudent application of loans for productive investments for growth cannot be overemphasized in this scenario.

\subsection{Empirical Studies}

Several studies have argued on this subject without meaningful consensus. These include a comparative study of Nigeria and South-Africa's external debts and the impact on economic growth from 1980 to 2007. Using the OLS technique, the study showed that external debt and external debt servicing negatively affected their economies [12]. Similarly, positive and negative relationships were established in the short and long terms respectively in research by [13] using causality, cointegration and VECM techniques between external reserves, economic growth, imports, money supply and public debt servicing in Nigeria from 1980 to 2014. [14] documented no positive effect of government debt on economic growth in an international study involving the United States, Germany, United Kingdom and Canada using ECM. [15] studied the link between fiscal policy and demands for international reserves in emerging countries using the two stage least square method and concluded that the connection was uncertain for highly politically risky countries. In a study of external reserves, external debts and 
economic development in Nigeria, it was discovered that for external reserves, the relationship was negative but significant in the short term and positively significant in the long term, while for external debt, it was positive but insignificant [6]. However, in related studies, external debts showed a positively significant effect on economic growth $[16,17]$. External reserves also displayed a positive and significant effect on economic growth $[2,18]$.

\section{Data and Methods}

This research work used secondary data for the period 1979 to 2019 sourced from the World Bank online database. The series used comprised of - real gross domestic product (RGDP), external debts (EXDT), external reserves (EXRS), inflation rate (INFR) and total debt service costs (TDS).

\subsection{Model Specifications}

This work is modelled according to the research work in [18], with slight modifications with regards to the variables and econometric methods employed. The primary model used external reserves, external debts, domestic debts, real gross domestic product and investments savings, etc. as variables, while this study will use real gross domestic product (RGDP), external debts (EXDT), external reserves (EXRS), inflation rate (INFR) and total debt service costs (TDS) (see equations 1 and 2).

$$
F E R_{i}=C_{i}+\beta_{1} E R_{i}, \quad[\mathrm{USD}]
$$

where: FER is Foreign Exchange Reserves [USD]; ER is Exchange Rate [USD/=N=]; USD is United States Dollar [\$]; and $=N=$ is Naira [Nigerian Currency].

$$
E X R S=\beta_{0}+\beta_{1} E X D T+\beta_{2} T D S+\beta_{3} R G D P+\beta_{4} I N F R+U_{t}
$$

where: EXRS, EXDT, RGDP, INFR, TDS are as defined above; TDS is Ratio of Total Debt Service to Gross National Income (GNI) [\%]; $\beta_{0}-\beta_{4}$ is parameters; and $U_{t}$ is error term.

Apiriori expectation $=0<$ EXDT $>0,0<$ EXRS $>0$, positive and significant

Model 2 will expectedly test the objective.

Definitions of Terms:

I. TDS - total debt service (\% GNI) is a combination of the amount of principal facility repayments and interest paid in currency, goods or services on long-term debt, interest paid on short-term debt, and repayments to the monetary fund.

II. EXDT - external debt is the proportion of a country's debt that is borrowed from foreign lenders and institutions such as commercial banks, foreign governments and international financial institutions. This is measured as a percentage of gross domestic product, and in other instances expressed as a percentage of gross national income.

III. RGDP - real gross domestic product is an inflation-adjusted rate of growth for goods and services produced in an economy in a given year expressed as a percentage.

IV. EXRS - external reserves, also known as foreign exchange reserves, represent assets held in reserve in foreign currencies by a country's monetary authority. These are used as back-up for the country's liabilities with attendant influence on monetary policy. It is measured as total reserves as a percentage of total external debt.

V. INFR - inflation rate is the general increase in the price level of goods and services over a defined period of time. 


\section{Results}

This segment focuses on the treatment of the variables of interest in this study, as highlighted in Section 2, using basic diagnostic and econometric tools.

\subsection{Diagnostic Tests}

The pretreatment tests carried out include descriptive statistics, stationarity tests, serial correlation tests, etc. These help prepare the various data for the application of linear regression analyses.

\subsubsection{Descriptive Statistics}

The results are presented in the following table (Table 1).

Table 1 Descriptive statistics. Source: [19]

\begin{tabular}{|c|c|c|c|c|c|}
\hline & EXDT & EXRS & INFR & RGDP & TDS \\
\hline Mean & 61.5444 & 89.3037 & 18.7559 & 3.2638 & 2.6372 \\
\hline Median & 51.1600 & 24.0800 & 12.2200 & 4.2100 & 1.8800 \\
\hline Maximum & 228.3700 & 444.3600 & 72.8400 & 15.3300 & 6.5200 \\
\hline Minimum & 4.1300 & 3.1500 & 5.3800 & -13.1300 & 0.1000 \\
\hline Std. Dev. & 59.1404 & 123.4357 & 16.7260 & 5.3612 & 2.0905 \\
\hline Skewness & 0.9396 & 1.6769 & 1.8629 & -0.9288 & 0.4886 \\
\hline Kurtosis & 3.2865 & 4.7927 & 5.3125 & 4.8392 & 1.8307 \\
\hline Jarque-Bera & 6.1734 & 24.7041 & 32.8501 & 11.6737 & 3.9670 \\
\hline Probability & 0.0457 & 0.0000 & 0.0000 & 0.0029 & 0.1376 \\
\hline Sum & 2523.3200 & 3661.4500 & 768.9900 & 133.8160 & 108.1230 \\
\hline Sum Sq. Dev. & 139903.5 & 609454.8000 & 11190.3900 & 1149.7030 & 174.8059 \\
\hline Observations & 41 & 41 & 41 & 41 & 41 \\
\hline
\end{tabular}

The results in Table 1 indicate that over $80 \%$ of the variables show an average kurtosis greater than 3, which indicates platykurtic characteristics, while $20 \%$ are below 3, indicating leptokurtic characteristics. At the $5 \%$ level of significance, the selected variables show significant Jarque-Bera statistics.

\subsubsection{Stationarity Tests}

This test confirms that the data in the model are stationary at a given level with a significant p-value.

Table 2 Stationarity test results. Source: [19]

\begin{tabular}{|c|c|c|c|c|}
\hline Variable & ADF Stat & Critical value @ 5\% & p-value & $\begin{array}{c}\text { Level of } \\
\text { integration }\end{array}$ \\
\hline EXDT & -6.0668 & -3.5298 & 0.0001 & I (1) \\
\hline EXRS & -4.8779 & -3.5298 & 0.0017 & I (1) \\
\hline INFR & -6.2332 & -3.5331 & 0.0000 & I (1) \\
\hline RGDP & -9.1213 & -3.5298 & 0.0000 & I (1) \\
\hline TDS & -6.3098 & -3.5298 & 0.0000 & I (1) \\
\hline
\end{tabular}

The probabilities of the selected series are significant and integrated at level one at a $5 \%$ confidence level. 


\subsubsection{Heteroskedasticity Tests}

Table 3 indicates no heteroskedasticity in the model as the F-statistic and Chi-square probability values are greater than the 0.05 level of significance and insignificant.

Table 3 Heteroskedasticity results using BPG. Source: [19]

\begin{tabular}{|c|c|c|c|}
\hline \multicolumn{4}{|c|}{ Heteroskedasticity test: Breusch-Pagan-Godfrey } \\
\hline F-statistic & 0.4573 & Prob. F(4,15) & 0.7658 \\
\hline Obs*R-squared & 2.1738 & Prob. Chi-Square(4) & 0.7038 \\
\hline Scaled explained SS & 1.3064 & Prob. Chi-Square(4) & 0.8603 \\
\hline
\end{tabular}

\subsubsection{Serial Correlation Tests}

The test results shows no autocorrelation in the series and in the model under consideration, with pvalues greater than the $5 \%$ chosen level of significance.

Table 4 Autocorrelation test results. Source: [19]

\begin{tabular}{|c|c|c|c|}
\hline \multicolumn{3}{|c|}{ Breusch-Godfrey serial correlation LM test: } & \\
\hline F-statistic & 0.3095 & Prob. F(2,13) & 0.7391 \\
\hline Obs*R-squared & 0.9089 & Prob. Chi-Square(2) & 0.6348 \\
\hline
\end{tabular}

\subsubsection{Ramsey Reset Tests}

The results of the Ramsey reset tests presented in Table 5 indicate that $\mathrm{t}$ - and F-statistics are both more than the accepted 5\% level of significance and therefore the model is well suited for the linear relationship.

Table 5 Ramsey reset test results. Source: [19]

\begin{tabular}{|c|c|c|c|}
\hline \multicolumn{4}{|c|}{ Ramsey reset test } \\
\hline \multicolumn{4}{|c|}{ Equation: UNTITLED } \\
\hline \multicolumn{3}{|c|}{ Specification: EXRS C EXDT RGDP(-2) INFR(-5) TDS(-4) } \\
\hline \multicolumn{4}{|c|}{ Omitted variables: squares of fitted values } \\
\hline & Value & df & Probability \\
\hline t-statistic & 0.3534 & 14 & 0.7290 \\
\hline F-statistic & 0.1249 & $(1,14)$ & 0.7290 \\
\hline Likelihood ratio & 0.1777 & 1 & 0.6734 \\
\hline
\end{tabular}

\subsection{Hypothesis Testing}

\subsubsection{Hypothesis Testing}

$\mathrm{H}_{0}$ : No significant relationship exists between external reserves, external debt, real gross domestic product and total debt service costs for Nigeria.

$\mathrm{H}_{1}$ : A significant relationship exists between external reserves, external debt, real gross domestic product and total debt service costs for Nigeria. The econometric techniques of ordinary least square, cointegration ranked trace and maximum eigenvalue tests were employed. 
Table 6 Ord. least square regression results. Source: [19]

\begin{tabular}{|c|c|c|c|c|}
\hline \multicolumn{5}{|c|}{ Dependent variable: EXRS } \\
\hline \multicolumn{5}{|c|}{ Method: least squares } \\
\hline \multicolumn{5}{|c|}{ Sample (adjusted): 1984 2003 } \\
\hline Included observations: 20 after adjustments \\
\hline Variable & Coefficient & Std. Error & t-Statistic & Prob. \\
\hline C & 25.1166 & 4.2671 & 5.8862 & 0.0000 \\
\hline EXDT & -0.1535 & 0.0369 & -4.1613 & 0.0008 \\
\hline INFR(-5) & 0.2684 & 0.0765 & 3.5089 & 0.0032 \\
\hline RGDP(-2) & 0.3402 & 0.3033 & 1.1217 & 0.2796 \\
\hline TDS(-4) & -0.3944 & 1.0283 & -0.3836 & 0.7067 \\
\hline
\end{tabular}

The results in Table 6 show that the OLS indicates that while external debt showed a negatively significant relationship with external reserves (with a p-value of 0.0008), there is an insignificant relationship to real gross domestic product (RGDP) and total debt service costs (TDS) since their probabilities are greater than the accepted 0.05 confidence level (p-values of 0.2796 and 0.7067 , respectively). The $\mathrm{R}^{2}(66.68 \%)$ and the adjusted $\mathrm{R}^{2}(57.80 \%)$, show that the variables in the series perfectly fit the model, with a Durbin Watson statistic of 1.6729 also indicating the absence of autocorrelation in the model.

\subsubsection{Testing for Causality}

The researchers attempted to ascertain if there is any degree of influence between the variables in the series;

Table 7 Granger causality test results. Source: [19]

\begin{tabular}{|c|c|c|c|}
\hline \multicolumn{4}{|l|}{ Pairwise Granger causality tests } \\
\hline \multicolumn{4}{|l|}{ Sample: 19792003} \\
\hline \multicolumn{4}{|l|}{ Lags: 2} \\
\hline Null Hypothesis: & Obs & F-Statistic & Prob. \\
\hline EXRS does not Influence EXDT & 23 & 1.2305 & 0.3156 \\
\hline \multicolumn{2}{|l|}{ EXDT does not Influence EXRS } & 2.0064 & 0.1634 \\
\hline INFR does not Influence EXDT & 23 & 0.4189 & 0.6640 \\
\hline \multicolumn{2}{|l|}{ EXDT does not Influence INFR } & 5.0355 & 0.0183 \\
\hline INFR does not Influence EXRS & 23 & 0.9931 & 0.3898 \\
\hline \multicolumn{2}{|l|}{ EXRS does not Influence INFR } & 0.6131 & 0.5526 \\
\hline RGDP does not Influence EXRS & 23 & 0.3627 & 0.7007 \\
\hline \multicolumn{2}{|l|}{ EXRS does not Influence RGDP } & 4.6080 & 0.0242 \\
\hline TDS does not Influence EXRS & 23 & 1.9490 & 0.1713 \\
\hline \multicolumn{2}{|l|}{ EXRS does not Influence TDS } & 3.6708 & 0.0460 \\
\hline
\end{tabular}

Comments: The Granger causality tests revealed a uni-directional significant relationship between EXRS and RGDP (p-value: 0.0242) and EXRS and TDS (p-value: 0.0460). This outcome implies that external reserves have a significant relationship with gross domestic product (by proxy RGDP) and total debt service costs (TDS), and that these variables affect the external reserves of a country. 


\subsubsection{Long Term or Cointegration Tests}

Having determined the short-term relationships, it is pertinent to ascertain whether a long-term relationship exists between the variables of interest.

Table 8 Cointegration rank test results (Trace). Source: [19]

\begin{tabular}{|c|c|c|c|c|}
\hline \multicolumn{5}{|c|}{ Sample (adjusted): 19812003} \\
\hline \multicolumn{5}{|c|}{ Included observations: 23 after adjustments } \\
\hline \multicolumn{5}{|c|}{ Series: EXDT EXRS INFR RGDP TDS } \\
\hline \multicolumn{5}{|c|}{ Lags interval (in first differences): 1 to 1} \\
\hline \multicolumn{5}{|c|}{ Unrestricted cointegration rank test (Trace) } \\
\hline Hypothesized & & Trace & 0.05 & \\
\hline No. of CE(s) & Eigenvalue & Statistic & Critical Value & Prob.** \\
\hline None * & 0.9555 & 142.1401 & 69.8189 & 0.0000 \\
\hline At most $1 *$ & 0.7314 & 70.5744 & 47.8562 & 0.0001 \\
\hline At most $2 *$ & 0.6643 & 40.3374 & 29.7971 & 0.0021 \\
\hline At most 3 & 0.4733 & 15.2316 & 15.4947 & 0.0547 \\
\hline At most 4 & 0.0210 & 0.4881 & 3.8415 & 0.4848 \\
\hline
\end{tabular}

The results of the cointegration trace tests presented in Table 8 show the existence of three cointegrating equations between external reserves, external debts, total debt service costs and real gross domestic product (RGDP). The results reveal that there is a long-term relationship between EXRS, EXDT, TDS and RGDP.

Table 9 Cointegration rank test results (Maximum eigenvalue). Source: [19]

\begin{tabular}{|c|c|c|c|c|}
\hline Hypothesized & & Max-Eigen & 0.05 & \\
\hline No. of CE(s) & Eigenvalue & Statistic & Critical Value & Prob.** $^{* * \mid}$ \\
\hline None $^{*}$ & 0.9556 & 71.5657 & 33.8769 & 0.0000 \\
\hline At most $1 *$ & 0.7314 & 30.2370 & 27.5844 & 0.0223 \\
\hline At most $2 *$ & 0.6644 & 25.1058 & 21.1316 & 0.0131 \\
\hline At most $3 *$ & 0.4733 & 14.7435 & 14.2646 & 0.0420 \\
\hline At most 4 & 0.0210 & 0.4881 & 3.8415 & 0.4848 \\
\hline \multicolumn{5}{|c|}{ Max-eigenvalue test indicates 4 long-term vectors at the 0.05 level } \\
\hline
\end{tabular}

The results of the cointegration rank maximum eigenvalue tests reconfirm and reinforce the existence of long-term relationships between the variables with p-values of 0.0000, 0.0223, 0.0131 and 0.0420 , respectively, which are below the chosen 0.05 level of significance.

Decision: The results from the OLS, Granger causality and cointegration tests reveal that at the level of significance of 0.05 , a significant relationship exists between external reserves, external debts, total debt service costs and economic growth (RGDP) (See Tables 6, 7, 8 and 9). The null hypothesis is therefore rejected and the alternative accepted, i.e. there is a significant relationship between Nigeria's external/foreign reserves and external debt, total debt service costs and economic growth. 


\section{Discussion}

This study investigated the nature of the relationships between external reserves, external debt, total debt service costs and economic growth from 1979 to 2019 in Nigeria. The econometric tools used included OLS regression, cointegration and Granger causality. The OLS tests conducted revealed that in the short term, external reserves showed a negatively significant relationship with external debt (with a p-value of 0.0008), while the relationship was insignificant for economic growth (0.2796) and total debt service costs (0.7069). This result supports the findings of [18] that foreign reserves have a significant effect on external debt, but contradicts the outcomes in $[14,15]$.

In determining the direction of influence, we observed that external reserves Granger-caused economic growth (RGDP) (p-value: 0.0242), and total debt service costs (TDS) (p-value: 0.0460). This outcome is corroborated by the findings of $[2,13]$. In the long term tests using Johansen ranked cointegration, we discovered the existence of cointegration vectors for external reserves, external debt, total debt service costs and economic growth. Hence, the series shows a long-term relationship even for variables such as economic growth (RGDP) and total debt service costs (TDS) which did not show a significant relationship with external reserves in the short term. This result is supported by the findings of [16] and affirmed by [12].

The policy implications of this result are that a $1 \%$ rise in the country's external debt will result in a $0.15348 \%$ drop in its external reserves, while a $1 \%$ rise in inflation rate will cause a $0.2684 \%$ growth in the volume of the nation's external reserves. Hence, policymakers are advised to adopt measures that will assist the external reserves of the country to grow, such as GDP growth and the reduction of debt service costs, as well as appropriate inflationary control mechanisms.

\section{Conclusion}

On the basis of the negative significant relationship found between external reserves and external debts in the short term and the significant long-term relationship between external reserves and external debt, and total debt service costs and economic growth, we can conclude that a significant inverse relationship exists in the short term only between external reserves and external debt and a significant relationship between external reserves and external debt, and total debt service costs and economic growth in the long term.

Based on the aforementioned, we recommend that the government and monetary authorities:

I. Reduce the creation of external debts due to their significant adverse effect on external reserves and to pursue domestic loan options that carry less stringent repayment terms; this will hasten the development of key sectors of the economy such as the transport sector.

II. Cautiously negotiate more favourable foreign fixed interest rate loans and tie repayments to proceeds from revenue generating projects that it will finance;

III. Engage in export-oriented economic and productive activities that drive the growth of external reserves, such as local oil refining and the export of petrochemical products, agricultural production and exports, transport infrastructure development etc.

\section{Acknowledgements}

We wish to thank the World Bank Group for the use of their online data base systems. The authors also wish to state that they have received no financial support from any individual or organization to carry out this research work. 


\section{References}

[1] Isibor, A.A., Babjide, A.A., Akinjare, V., Oladeji, T. \& Osuma, G. (2018). The Effect of Public debt on Economic Growth in Nigeria: An Empirical Investigation. International Business Management 12(6), 436-441. DOI: 10.36478/ibm.2018.436.441.

[2] Central Intelligence Agency CIA (2013). World Fact Book. ISBN: 16160-88230

[3] Mojekwo, J.N. \& Ogege, S. (2012). Nigeria Public Debt and Economic Growth: A Critical Appraisal. The Business and Management Review 07(1), 125-145. ISSN 2476-847.

[4] Victoria, S., Emmanuel, O., Obinna, U., Esther, S. \& Akinde, O. (2016). Public Debt and External Reserves: The Nigerian Experience (1981-2013). Economic Research International. DOI: $10.1155 / 2016 / 1957017$.

[5] Osadume, C.R. \& Okene, J.A. (2019). External reserves, external debts and economic development: Lesson Nigeria, 1980-2018. British Intl. Journal of Education and Social Sciences 6(1). ISSN 2222-2855.

[6] Nzotta, S.M. (2004). Money, banking and finance: Theory and practice. Hudson-Jude Nig. Publishers. Finance and Banking Research 5(5). Retrieved July 20, 2020, from https://ssrn.com/abstract=1534212

[7] Central Intelligence Agency CIA (2002). World Fact book. ISBN: 16079-64015.

[8] Essien, S.N., Ngozi, T.I., Michael, K.M., \& Ogochukwu, G.O. (2016). An Empirical Analysis of the Macroeconomic Impact of Public Debt in Nigeria. CBN Journal of Applied Statistics 7(1). Retrieved on July 10, 2020, from http://hdl.handle.net/10419/142116

[9] Obaseki, P.J. (2007) Foreign exchange management in Nigeria. Past, present, and future, CBN Economic and Financial Review 39(1), 12-223. ISSN 1957 - 2965.

[10] Ogege, S. \& Ekpudu, J.E. (2010). The effects of debt burden on the Nigerian economy. Journal of Research in National Development 8, 50-65. DOI: 10.4314/jorind.v8i2.66829.

[11] Ayadi, F.S. \& Ayadi, F.O. (2008). The Impact of External Dent on Economic Growth: A Comparative Study of Nigeria and South Africa. Journal of Sustainable Development in Africa 10, 234-264. ISSN: 1520-5509.

[12] Akpan, E. \& Ala, T. (2016). Causality between External Reserves, Economic Growth, MoneySupply and Public Debt Servicing: Evidence from Nigeria. Research Journal of Finance and Accounting 7(2), 1-7. DOI: 10.7176/RJFA.

[13] Kaluluma, P. (2002). Effect of Government Debt on Interest Rates: Evidence from Causality Test in Johansen- Type Models. Repec. Econ. Papers. Retrieved from econpapers.repec.org/RePEc:shr:wpaper:02-07

[14] Zhou, Y. (2009) International Reserves and Fiscal Policy in Developing Countries SCCIE. Working Paper \#06-18 Santa Cruz Center for International Economics. DOI: 10.1111/j.14679396.2008.00803.x.

[15] Faraji, K. \& Makame, A.S. (2013). Impact of External Debt on Economic Growth: A Case Study of Tanzania. Advances in Management and Applied Economics, 3(4), 59-82. ISSN 1792-7544 (print version), 1792-7552 (online).

[16] Zaman, R. \& Arslan, M., (2014). The Role of External Debt on Economic Growth: Evidence from Pakistan Economy. Journal of Economics and Sustainable Development 5(24), 140. Corpus ID: 55035120

[17] Alam, M.Z. \& Rahim, M.A. (2013). Foreign Exchange Reserves: Bangladesh Perspectives. International Journal of Finance and Banking Studies 2 (4), 1-12. ISSN: 2147 - 4486.

[18] Osadume, C.R. \& University, E.O. (2021). Authors E-Views 10 Computations, 2021. Derived from E-views 10 statistical software.

[19] World Bank Group (2020). World Bank, International Debt Statistics, 2020. ISBN (paper): 978-14648- 1610-9, ISBN: 978-1-4648-1611-6. DOI: 10.1596/978-1-4648-1610-9.

[20] Igwe, C. N., Oyelola, O. T., Ajiboshin, I. O., \& Raheem, S. (2013). A Review: Nigeria's Transportation System and the Place of Entrepreneurs. Journal of Sustainable Development Studies, 3(2), 168-180.

[21] Walker, G. J. (1959, as cited in Igwe et al, 2013). Traffic and Transport in Nigeria: The Example of an Under-developed Tropical Territory. Her Majesty's Stationary Office, London.1959 